\title{
Lapurdum
}

Euskal ikerketen aldizkaria | Revue d'études basques |

Revista de estudios vascos | Basque studies review

$10 \mid 2005$

Numéro X

\section{Iparraldeko azken aldiko literatura euskal literatur sistemaren argitan (eta vice versa)}

Zenbait hipotesi

Ur Apalategi

\section{(2) OpenEdition}

Journals

Édition électronique

URL : http://journals.openedition.org/lapurdum/32

DOI : 10.4000/lapurdum.32

ISSN : 1965-0655

Éditeur

IKER

Édition imprimée

Date de publication : 31 décembre 2005

Pagination : 1-18

ISBN : 2-86781-409-X

ISSN : $1273-3830$

Référence électronique

Ur Apalategi, « Iparraldeko azken aldiko literatura euskal literatur sistemaren argitan (eta vice versa) », Lapurdum [Linean], 10 | 2005, Sarean emana----an 01 avril 2008, kontsultatu 21 septembre 2020. URL: http://journals.openedition.org/lapurdum/32 ; DOI : https://doi.org/10.4000/lapurdum.32 


\title{
Iparraldeko azken aldiko literatura euskal literatur sistemaren argitan (eta vice versa). Zenbait hipotesi. ${ }^{1}$
}

Ur Apalategi, UPPA

\begin{abstract}
"Emazteen literatura", "haur eta gazte literatura", "Ipar Euskal Herriko literatura"... Hainbat kategoria berezko esanahia luketen errealitateak balira bezala begiratu izan direnak ia beti, ikuspegi esentzialista batetik. Behar bada, baina, merezi luke begirada berri batekin aztertzea "Ipar Euskal Herriko literatura" deritzona. Alegia, merezi luke "Euskal literatura" izeneko sistemaren pieza bat bezala begiratzea, eta sistema horretan zer funtzio betetzen duen jakiten saiatzea. Hori egiten ahaleginduko gara azken urteotako Iparraldeko literatur zenbait joera eta autore erabiliz.
\end{abstract}

Bi hitz, beraz, ibilbide honi hasiera emateko, literatur sistemaren kontzeptuaz.

\section{1-Literatur sistema edo esparrua}

Literatura balore unibertsalen esparrua da eta idazleek beti hala aurkezten dute. Arteak (eta beraz literaturak) ez dute mugarik ezagutzen. Baina errealitateari hurbilagotik begiratzen badiogu ohartuko gara gauzak ez direla hain sinpleak. Izan ere, bitxia bada ere, badirudi garai historiko bakoitzean nazio batzuetako idazleei errazagoa zaiela "unibertsalak" izatea beste nazio batzuetakoei baino. Adibide bat: nola irakurriko dugu Jean-Paul Sartre-ren Goragalea liburua? Giza kondizio unibertsalari buruzko gogoeta bezala, bistan da. Inori ez zaio bururatuko Paristar idazle baten lekukotasun "etnografiagarria" bezala irakurtzea. Ba ez da gauza bera gertatzen urte batzuk beranduago idatzitako Txillardegiren Leturiaren egunkari ezkutua-rekin. Beste hizkuntza batera itzuliko balute garbi dago lehen-lehenik euskal autore baten lana ikusiko luketela, eta ez balore unibertsaldun gogoeta bat bezala. Nolanahi ere, Txillardegiren liburua ez dute itzuli eta ez dute itzuliko, besteak beste euskarazko literatura literatura periferikoa delako mundu mailan. Bistan da, adibidea gaizki hautatua da (Txillardegi Sarteren epigonoa izan zen). Baina balio du zera frogatzeko: munduko literatur sistema ez dela mugarik gabea. Sistema internazionala da. Hots, nazioartekoa. Beraz, nazioek osatua. Horren frogarik sendoena da munduko eskola guztietan bertako literaturaren historia irakasten dela eta ez beste inongoa (Atxagak behin salatu zuenez ${ }^{2}$ ). Frantzian Frantziakoa, Ingalaterran bertakoa, etabar. Literatur sistemak nazionalak dira, definizioz. Esparru politiko nazionalaren sorrerarekin zerikusia duelako beti literatur tradizio nazional baten sorrerak. Izan ere, nazioak literaturaren beharra badu da nazioa sorkuntza literarioa delako neurri handi batean. Noiz hasten da existitzen nazio bat? Bada, literatur tradizio propioa aldarrikatzen hasten denean. Espainiak eta Frantziak, adibidez, XV. eta XVI. mendeetan egin zuten hori, latina utzi eta gaztelaniaz zein frantsesez literatura egiten hasi zirenean. Europako beste herri askok XIX. mendean egin zuten iraultza nazionala (herri nordikoek, eslaboek) eta ordukoak dituzte, nola ez, beraien tradizio nahiz hizkera literarioa. Egungo munduko literatur sitema XVI. mendean (edo lehentxeago Italian) hasi zen egituratzen nazio ezberdinez osaturiko metasistema gisa. Metasistema honetan, aurrena hasi zirenak asko hazteko astia izan dute (klasikoz hornitu dira eta klasikook unibertsaldu dituzte itzulpenen bitartez) eta

\footnotetext{
${ }^{1}$ Testu hau Getxoko kultur etxean «Iparra galdu gabe » kultur programaketaren barnean Euskal Kultur Erakundeak gonbidaturik 2004eko maiatzaren 4ean emandako mintzaldi baten bertsio eguneratua da.

${ }^{2}$ B.Atxaga, Horas extras, Madrid, Alianza, 1997, p.93.
} 
zenbat eta beranduago hasia izan eta periferikoagoa da literatur sistema nazional bat. Gaur egun, Europa mailan, gunean aurkitzen diren literatur sistema nazionalak Ingelesa, Frantsesa, Espainola, Italiarra eta Alemana dira (portugaldarra hein txikiago batean). Gainontzekoak perferikoak dira, eta periferikotasuna azkarragoa ala txikiagoa izan daiteke. Bada, gune / periferia mozketa hau modu berean ematen da literatur sistema nazional bakoitzaren barnean ere.

Hala, literatur sistema nazionalak hiriburu literario baten inguruan ardazturik egituratzen dira eskuarki (barneko gunea / periferia; guneko idazleak / periferiakoak; guneko obrak -kanonizatuak- I periferiakoak; guneko generoak -Gallimarden kolekzio txuria- / periferiakoak -kolekzio beltz, larrosa, regionala edo antzekoak-). Ulertuko zenez, egituraketa hau botere harreman baten irudia da: batzuk nagusi eta legitimo dira besteak menperatuak diren bitartean. Literatur sistema nazional baten gunean aurkitzen den idazleari ez zaio inoiz galdetuko nongoa den edo zein hizkera darabilen, baizik eta zertaz idazten duen eta zein den bere estiloa (guneko idazleari aurresuposatzen zaio gai eta problematika unibertsalak lantzen dituela bere obren bitartez). Aldiz, sistema horren periferian dagoen idazleak beti justifikatu edo bederen azaldu beharko du nongoa den (sistemaren zein eskualdetik edo "nondik" idazten duen ; eta normalean berarengandik zera espero da, bere periferiaren berri eman dezan) eta zergatik aukeratu duen bere periferiako hizkera erabiltzea (aukera hori egin badu). Zergatik, bada, "naturala" guneko hizkera erabiltzea litzatekeelako, hots, gunera asimilatzea. Saizarbitoriari (bizkaitarra izanagatik) ez zaio inoiz galdetu zergatik idazten duen batueraz, bai ordea Bizkaitar zein Iparraldetar idazleei zergatik aukeratzen duten bizkaiera edo Iparraldeko euskalkiak erabiltzea. Atxagari Euskal Herrian ez dio inork galdetu zergatik idazten duen batueraz eta bere obra bizitzari buruzko gogoeta unibertsal edo unibertsalizagarri gisa irakurri dugu. Baina Atxaga, Espainiar literatur sistemaren barnean autore erregionala da neurri batean, hortaz periferikoa eta beti justifikatu behar izaten du euskaraz idazteko aukera. Beti irakurri da Atxaga (espainiar estatuan) Euskal Herriaren berri ematen duen idazle modura, eta ez soilik munduaren berri edo giza-kondizioaren berri ematen duen idazle modura. Berriro gure sistemara itzultzeko, Bizkaieraz edo nafar-lapurteraz idaztea ez da "naturala", beti ikusten da aldarrikapen bat bezala (behintzat Euskal Herri osorako argitaratzen direnean lan hauek) eta beti irakurtzen dira aukera hau egiten duten idazle hauek euren probintziako berezitasunaren lekukotasuna ematen duten idazleak legez. Eta beste pretentsio bat edukitzea debekatzen zaie edo bestela, periferiako idazleengandik espero dena da (batez ere esparru osorako idazteko pretentsioa baldin badute) gunearen hizkera beregana dezaten. Baina, kontua da, guneko idazleek bezala idazteko "gunetar" bihurtu beharra dagoela eta hori ez da erraza (batzuek lortzen dute, ikus bestela Sarrionandia). Edo bestela aukera bat geratzen zaio periferiako idazleari: gunearen funtzionamendua aldatzea, gunea gune egiten duten balore eta edukiak ordezkatzea iraultza literarioa eginez. Hori oso aldi bakanetan gertatzen den gauza da, eta gertatzen denean ere eskuarki testuinguru historiko-soziologikoaren aldaketa batek lagunduta gertatzen da.

Beraz, literatur sistema beti da borroka eremu bat, hain zuzen zilegitasun literarioa edo "naturaltasuna" eskuratzeko lehia eremua. Jakina, deskribatu dugun honek guztiak bakarrik balio du literatur sistema egituratuta dagoen garaietarako. Baina kontua da noizbait literatur sitema bakoitza egituratzeke egon izan dela, eta garai haietan gauzak bestelakoak zirela. Gure kasuan, garbi dago kontzientzia literarioa (eta ez linguistikoa) XIX. mendearen hondarrean hasten dela garatzen, Pizkundearekin, Lore-jokoekin etabar, nahiz eta gerraurreko urrezko hamarkada (1927 Euskaltzaleak elkartearen sorrera-1937 Lauaxetaren fusilaketa) izango den 
benetako protosistema baten kimatze aroa. Bada, garai horietan (XX. mendearen lehen erdian), oraindik ez dago oso argi zein izango den euskal literatur sistemaren hiriburua (hiriburua diodalarik errekurtso editorial, humano eta sinbolikoetaz ari naiz, hots, kapital edo ondasun sinboliko literario gehiena metatzen den tokiaz). Alde batetik, euskalkietan aberatsena eta landuena nafartar-lapurtera da. Bestetik Bilbo eta Donostia ere legitimitate literarioa lortzeko lehian sarturik ikusten ditugu, argudio ekonomiko zein demografikoak berauen alde dituztelarik. Iparraldeko euskalki nagusiarekiko erakarpena ez da desagertuko oso berandu arte. Gogora bedi Federiko Krutwig, Aresti eta orohar "heterodoxoen" belaunaldiko ia guztiek, alegia euskara batua gauzatu zuten guztiek, gehiago ala gutxiago nafar-lapurtera aldeztu zutela. Baina, nago ez ote den joera berantiar hori dagoeneko Donostiak eta batuera txillardegiar-gipuzkoarrak mendean hartu duen sistema baten periferiatik egindako iraultza ahalegina. Nik uste Donostia eta gipuzkera Txomin Agirrek Garoa idazteari ekingo dionean hasiko direla nagusitzen gure sisteman. Hau da, Ondarroarra bizkaiera utzi eta gipuzkeraz idazten hasten denean. Hortik aurrera bizakaiera egituratzen ari den literatur sitemaren periferian mugituko da beti, Iparraldeko euskalki nagusia bezala. Asko dira, geroztik Bilbo Euskal Herriko hiriburu literario gisa aldarrikatu nahi izan dutenak (besteak beste Aresti bilbotarra, baina baita gipuzkoarra izanagatik donostiarra ez den Atxaga ere). Hauei beti huts edo kale egin diena da ez zegoela lotura berezkorik nagusitu zen euskara eredua eta Bilboren artean (eta ez Bilbon jendea bizkaieraz ari zelako, baizik eta sinpleagoki Donostian ez bezala, Bilbon ez zelako apenas euskararik egiten). Gainera Bilbo aldarrikatu duten idazle hauek ez dute inolaz ere bizkaiera aldarrikatu idazteko tresna gisa.

Oso bestelakoa da Iparraldeari gertatu zaiona. Iparraldearen arazoa, lehenlehenik demografikoa eta ekonomikoa da, ez baitzuen eskaintzen hiriburu literario bihurtzeko azpiegitura aski sendorik, nahiz eta testu literarioei zegokienean eskualderik aberatsena izan azken mendearen erdirarte (eta nahiz eta irakurlego ohituena eta trebatuena eduki). Horrela, mendea aitzina joan ahala, Iparraldeko euskalki literario nagusia zera bihurtuz joan da: Hegoaldeko heretiko zein heterodoxo guztien alibi-a. Oso modan zegoen, guztiz chic-a zen (eta oraindik ere bada neurri batean) Hegoaldeko idazleentzat Iparraldeko hitzez eta itzuli linguistikoz zipriztintzea beren testuak. Mugimendu hau jadanik indarrean ikusten dugu bigarren Pizkundeko liriko handiengan: Lauaxetaren Arrats beran bilduma "iparraldismoz" josia ageri zaigu eta gauza bera esan daiteke Lizardiren obra osoaz. Ordurarteko tradizio literario aberatseneko euskalkia izanki Iparraldekoa, autore hauek nolabaiteko prestigio literarioz kutsatu nahi dituzte beraien testuak eta hori dela eta jotzen dute eremu linguistiko dagoeneko periferiko horren ondarera. Kutsu literarioa ematen die testuei Iparraldeko elementuak txertatzeak. Baina, une berean, erabat Iparraldeko hizkera literarioz idatzitako testuak gure literatur sistemaren bigarren mailara jaisten dira batbatean eta betirako. Periferiko bihurtu dira. Azken urteotan egin dira saiakera batzuk Eskualduna kazetaren inguruan finkatu zen Iparraldeko hizkera literarioa erreformatzeko, modernizatzeko, problematika literario berrietara egokitzeko. Eta kurioski ez bakarrik Iparraldean bertan baizik eta euskal sistemaren gunetik (Hegoaldetik) ere izan da aldaketa horrekiko erresistentziarik. Ibon Sarasola euskaltzainak (zaindari hitza hemen ezin egokiagoa delarik bere jarrera deskribatzeko) gogorki kritikatu du 90eko hamarkadaren bukaeran zenbait idazlek (Bordak, Lukuk) buruturiko berrikuntza lana. Eskualduna-Herria aldizkarietan garatu zen Iparraldeko nafar-lapurteraren patrimonializazio edo sanktuarizazio bat bide da Sarasolaren helburua. Euskara batuarentzako stock linguistiko aratz bat bihurtu da Iparraldeko euskalki literario nagusia ikuspegi honetan, eta horrela bakarrik onartzen 
zaio euskara nazionalaren eraikuntza prozesu loriatsuan esku hartzeko eskubidea. Iparraldeko idazle periferikoek -eta periferikotasunera betirako kondenatuak dirudite ikuspegi higiezin horretan- erreserba linguistiko batean bizi behar lirateke, Iparraldeko hizkera tipikoaz mintzatzera edo idaztera beharturik. Hemen orain deskribatzen saiatuko naizena, beraz, munduko literatur sistema nazioartekoan arras periferikoa den gure euskal literatur sistema xumearen periferian aurkitzen den azpisistema literario bat $\mathrm{da}^{3}$ : Iparraldeko euskarazko literatura. Periferiaren periferia beraz. Panpin errusiarren joko bat bailitzan guztia...

\section{2-Egungo Iparraldeko literatur azpi-sistema: bere aktoreak eta estrategia motak}

\section{1-Azpi-sistemaren egitura. Daniel Landarten zentraltasuna}

Beti gune bakar batez eta periferia askoz osatzen den sistema edo azpisistema baten funtzionamendua aski konplexua da. Izan ere, gutxienez gunekoa izateko bi modu daude eta beste bi periferiakoa izateko. Alde batetik, guneko idazleak bi motatakoak dira: jatorrizkoak (gunean sortu direnak eta guneko ohitura eta jokamoldeei egokitzeko indar berezirik egin behar ez dutenak) eta asimilatuak (jatorriz periferikoak direnak baina euren sortzezko tasunak baztertu eta gunekoak bereganatzeko esfortzua egin dutenak). Jatorrizko ala asimilatu izan, honek ez du baldintzatzen hierarkian bakoitzak lortu dezakeen tokia. Badira asimilatuak gailurrera igotzea lortu dutenak (Sarrionandia) eta jatorrizkoak modu berean goia jo dutenak (Saizarbitoria). Era berean, jatorrizko nahiz asimilatu izan, asko dira gunearen frakasatu izatera kondenatuak (eta gehienetan erdi-anonimatoan edo guztizkoan bizi dira). Beste aldetik, periferiako idazleak ere bi motatakoak dira : periferia jomuga bakartzat daukatenak (periferiako irakurlego naturalarentzat idazten dutenak, beste anbiziorik gabe) $)^{4}$ eta periferiatik alde egitea nahi ez duten arren guneko irakurlegoa ere bereganatzeko asmoa dutenak. Azken hauek gunearen asimilatuak bihurtzerik ez dute nahi eta euren anbizio nolabait esateko "nazionalak" de facto iraultzaile bihurtzen ditu, zeren guneko irakurlegoa lortzeko gunearen baloreak irauli eta aldarazi behar baitituzte ezinbestean. Ez dezagun begibistatik galdu, halere, nafarlapurtera Iparraldeko azpi-sistemaren gunea dela, eta hortaz jatorrizkoak eta asimilatuak aurkituko ditugula baita ere azpi-sistema honen gunean.

Oinarrizko kategoria hauek eskuartean ditugula has gaitezke egungo Iparraldeko idazleak sailkatzen.

Iparraldeko literatur azpi-sistema euskal sistemaren periferian aurkitzen denez, abia gaitezen baieztapen sinple honetatik: definizioz ez dugu aurkituko euskal sistemaren guneko jatorrizkoen artean Iparraldeko idazlerik. Asimilatuen sailean teorikoki posible da halakorik aurkitzea, alegia, batuera estandarrean eta guneko literatur problematika eta temarioa landuko lukeen idazlea. Gero itzuliko naiz halakorik eman den ala ez aztertzera. Baina goazen lehendabizi euskal sistemaren

\footnotetext{
${ }^{3}$ Menpekotasun egoera horren zantzu garbi eta eztabaidaezina honakoa da : Iparraldeko autore nagusiek Hegoaldean argitaratzen dituzte lanak.

${ }^{4}$ Hauetaz esan daiteke kasik ez direla periferiko sentitzen; sistema txikiago baten gune sentitzen direla. Baina mundutik moztuta egongo behar luke halako idazle batek, edo autista izan behar luke, bere izaera periferikoaz ez ohartzeko (euskal sistema orokorrean kokatuz gero).
} 
periferian, Iparraldean eta Iparraldeko problematika zein temarioa baliatuz idazten duten autoreak aztertzera eta sailkatzera. Idazle hauek jatorrizkoak ala asimilatuak izan daitezke, azpi-sistema honen gunean aurkitzen direlako. Jatorrizkoen artean eta beraz azpi-sistemaren gailurrean edo periferiaren gunean, arrakasta lortu dutenak aintzat hartuz noski, legitimoena eta naturalena, Daniel Landart dela esango nuke. Adinak ere laguntzen dio eta heldutasun biologiko nahiz artistikora iritsitako idazle baxe-nafartarra da azpi-sistemaren gune izan diren iraganeko idazleen oinordekoa. Honek ez du esan nahi ez denik iraultzailea izan bere garaiean. Baina bi iraultza bereizi beharko genituzke hemen: belaunaldi ordezkaketarekin zerikusia duena (eta hor borroka ideologikoak egon daitezke tartean) eta sistemaren zilegitasuna kordokarazi nahi duena ${ }^{5}$. Nire uste apalean Daniel Landart lehen taldeko iraultzaileen artean kokatu behar litzateke: Iparraldeko gizarte berrian esanahia galdu zuten temario eta forma zaharkituak -aurreko idazle belaunaldienak- berritzen jakin zuen orain dela bi edo hiru hamarkada eta gizarte berri horrek eman zion onespena izan zen belaunaldi aldaketa gauzatu zuena sistema literarioaren barruan. Kategoria berean sartuko nuke, nahiz ez duen Landartena bezain kurrikulum aberatsa, Pantzo Hirigarai antzerki egilea. Eta ez da kasualitatea antzerki egile bat izatea zerrendako bigarrena. Izan ere, Iparraldeko azpi-sistema literarioaren berezitasunetako bat baita antzertiak duen zentraltasuna. Euskal sisteman, eleberrigintza bihurtu bada azken hogei urteotan guneko genero bakarra (gainerakoak -alegia olertia, antzertia, saiakera,...- sistemaren periferiara bidaliz) ez da hala gertatu Iparraldean. Noski, eleberrigintzak, edo prosak orokorrean, badu tradiziorik eta indarrik, baina genero herrikoi eta arrakastatsuena antzertia da oraindik ere $^{6}$. Iparraldeko azpi-sistemaren gunean asko dira antzertiarekin zerikusia duten idazleak, hala nola Daniel Landart bera (prosagile edo kantariek hartutako olerkiegile gisa bezain ezaguna baita garai

\footnotetext{
${ }^{5}$ Hipotesi modura, eta norbaitek noizbait sakonduko duelakoan, esan dezadan nire ustez belaunaldi ordezkaketarekin zerikusia duten iraultza literarioetan tematika erreferentzialideologikora mugatzen direla berrikuntzak. Aldiz, sistema bera kordokan jarri gogo duen iraultza ematen denean, badirudi hizkera literarioa bera (medium-a, beraz, eta ez hainbeste edukia) dela aldatzen dena. Hala, esan liteke Lizardi-Lauaxeta binomioaren euskara literario eredu berria euskal literatur sistema (edo esparru) nazional bakarraren aldarrikapena dela. Euskalki ezberdinei maileguak eginez eta Sabino Aranaren arautegi ortografiko zein lexikologikoak praktikan ezarriz ordurarte nagusi zen ikuspegi eskualdekoiarekiko haustura gauzatzen dela. Gauza bertsua agituko da hiru hamarkada beranduago, heterodoxoen belaunaldiak (Mirande, Krutwig, Txillardegi, Aresti) euskara batuaren aldeko apustua egingo duenean. Euskal esparru literario bateratuaren aldeko gerraurreko saio hilaurtuaren errepikapena besterik ez da (jakina, aranismo linguistiko-ideologikoaz purgaturik). Hipotesi hau baliagarria bada, garbi geratzen da zergatik sailkatu dugun Daniel Landart belaunaldi ordezkaketa bilatzen duten iraultzaileen artean. Daniel Landartek ez du hautsi EskualdunaHerria aldizkarien euskara ereduarekin. Aitzitik, Iparraldeko literatur azpi-sisteman bere lehiakide nagusia den Itxaro Borda batek horixe leporatu izan baitio behin eta berriro prentsan eginiko adierazpenen bitartez.

${ }^{6}$ Esan daiteke Iparraldeko literatur sistema, generoen indar erlatiboei dagokienez, Euskal sistema baino askoz ere orekatuagoa dela ; poesiak oraindik indar pixka bat badu, prosagintza ez dago erabat eleberrigintzak fagozitaturik eta antzerkigintza osasuntsu ageri zaigu. Halere, egoera orekatu hau ez da baitezpada seinale ona : izan ere, ahozkotasunarekin zerikusia duten generoen indar handiak (antzerkigintza, eta olerkigintza neurri txikiago batean) zera salatzen baitu : biztanleriaren alfabetatze maila txikia. Gutxi dira, egungo Iparraldean liburu bat, eta are gutxiago eleberri oso bat, irakurtzeko eta gozatzeko gai direnak. Askoz gehiago, aldiz, antzerki bat ikusteko eta ulertzeko gaitasuna dutenak.
} 
bateko Iparraldeko antzerkigintzaren berritzaile gisa).

Egia esateko, eta beti panpin errusiarren metaforari eusteko, nafar-lapurtera izeneko euskalki literarioa Iparraldeko literatur azpi-sistemaren gune ere bada, zuberera literarioa delarik bere periferia. Eta hemen ere lehen erakutsi dugun moduan errepikatzen dira mekanismo guztiak : adibidez asimilatuak aurkituko ditugu (nafar-lapurteraz idazten duten xiberotarrak, etb.). Iparraldeko literatur sistemaren guneko asimilatuak egon badaudeke gaur egun, hots, xiberotarrak edo, zergatik ez Euskal Herriko beste eskualde batekoak, nafar-lapurteraz ("manexez") eta azpisistemaren problematika eta eremua gogoan dituztela idazten dihardutenak. Baina, nik dakidala, ez arrakasta handia lortu duenik.

\section{2-Itxaro Borda edo periferiatik erdiguneranzko bidaia amaigabea}

Goazen orain Iparraldeko literatur azpi-sisteman periferikoak diren idazleak aztertzera. Periferikoetan garrantzitsuena den autorea, dudarik gabe, Itxaro Borda dugu. Behar bada harrigarria dirudi Borda bezain mediatikoa eta itxuraz arrakastatsua den idazlea (duela bi urte Euskadi saria lortua, gainera) periferikoen artean kokatzea, baina hala da. Iparraldeko azpi-sisteman oraindik ere, neurri handi batean, periferikoa izaten jarraitzen duela uste dut. Baina egungo Iparraldeko literatur azpi-sisteman eta baita Euskal sistemaren baitan Itxaro Borda zer den ulertzeko, beharrezkoa dugu iraganera jotzea, idazten eta argitaratzen hasi zen urteetara.

80eko hamarkadaren hasieran, Itxaro Borda gune-guneko Herria eta jite bereko aldizkari "legitimoetan" idazten hasten den idazle "arrunta" da. Baina laster, giro kontserbatzaile hori utzi eta beste idazle multzo batekin batera Maiatz aldizkari literario berriaren abenturari hasiera emango dio. Aldizkari berri hau Hegoaldeko Trantsizio garaieko Pott, Oh Euzkadi eta enparauen ildo beretik doa puntu askotan: literaturan espezializatzeko xedea, literatur erreferentzia unibertsalak (nazioartekoak) gurera ekartzeko asmoa, etb. Halere, Maiatzekoek, orohar, Iparraldeko hizkera literarioari eutsiko diote (nahiz egia den Hegoaldeko idazleek ere aldizkariaren orrialdeak beti zabalik izango dituztela baita euskara batuan idatzi gogo dutenek ere). Laburbiltzeko, Maiatz hurbilxeago legoke belaunaldi iraultza batetik sistema aldatzeko iraultzatik baino. Itxaro Borda ez da baina horretan geratuko. Bere burua periferikoegi ikusten bide du Iparraldeko idazle eta behar bada emazte gisa ere (bere ibilbidearen hastapenetik Euskal Herri osoaren mailan pentsatzen duelako bere tokia), eta 1984ean Basilika eleberri satiriko-polemikoarekin bere periferikotasunetik ateratzeko lehen saio serioa burutuko du. Jakina, Basilika eleberriak belaunaldi iraultzarekin zerikusia izaten jarraitzen du, bere eduki ideologiko-erreferentziala aurreko belaunaldien aurkako eraso bortitza baita (elizkoikeriaren kritika, rock kultura gaztearen aldarrikapena, Iparraldeko notable kulturalen karikatura erasokorra). Halere, ez da horretara mugatzen eleberritxo honen ekarpen iraultzailea. Bere egituraketan eta barne-hierarkian ondo baino hobeto gakotua ikusten duen Iparraldeko azpi-sistema literarioa korto-zirkuitatzeko ahalegina da Basilika batez ere. Ordurarte ez bezala euskara batuan idatziz, Itxaro Bordak Iparraldeko azpisistemaren legitimitatea bera dudan jarri eta Iparraldeko idazleentzat euskal sistema orokorretik idazteko eskubidea aldarrikatzen du. Ikuspuntu honetatik, esan daiteke sistema bera aldatzeko iraultza egiten saiatzen dela idazle baxe-nafartarra. Ez da uste behar, haatik, hau egiten lehena izan denik Itxaro Borda. Aitzindari entzutetsu eta garrantzitsurik izan izan du horretan. 
Gune baten dominaziotik ihes egiteko, edo menpekotasuna saihesteko modu oso eraginkor bat bada eta honetan datza: sistematik ines egitea sistema azkarrago batera jauzi eginez. Hau da Atxaga batek orain dela hamabost urte egin zuena gazteleraz idazten hasiz eta idazle espainol izaera eskuratuz (bere testuen itzulpenak beste norbaitek egingo balitu ez litzateke idazle espainola, baizik eta gure sistemako autore exportatua). Eta hau bera egin zuten Mirande eta Peillen bezalako zuberotarrek orain dela ia 50 urte batuera aukeratuz eta euskal sistemara salto eginez nafar-lapurteraren menpe zegoen Iparraldeko azpi-sistema atzean utziz. Jokamolde hau da, hain zuzen, Itxaro Bordak Basilika izeneko eleberria euskara batuaz idatzi eta plazaratu zuenean bereganatu zuena.

Arazoa da Mirande bat euskal literatur sistema egituratzen ari zen unean iritsi zela eta egituraketa horretan zuzenean esku hartu zuela. Euskara batua objektu teoriko hutsa zen garaiean hasi zen Mirande bere testuak ekoizten eta, neurri batean, Mirande eta bere belaunkide ziren idazle taldexka batek (heterodoxoen taldexkak) sortu zuten sistemaren guneko bihurtuko zen hizkera literarioa. Aldiz, Borda gure literatur sistema nazionalaren oholtzara igotzen den unean gauzak nahiko egituratuta daude. Euskara batuak baditu jada bere klasikoak, Donostia bereganatzen hasia da hiriburu izateko ondare sinbolikoa eta horrek guztiak zera dakar, zaila dela, gunean jatorrizkoa ez den idazle hasi berri batentzat guneko gotorlekura sartzea. Itxaro Bordak ez du lortuko beraz, bere lehen etapa horretan euskal sisteman eskuratu nahi lukeen tokia. Hau da, ez da iritsiko garaikide dituen Hegoaldeko idazleen parera.

Itxaro Bordaren lehen xedea beraz (Basilika batueraz idatzi eta Hegoaldean argitaratu $^{7}$ zuen unekoa) bikoitza zen: batueraz eta Donostia hiriburu zuela garatzen ari zen euskal sistemaren gunera asimilatzen saiatuz Iparraldean gazte eta emazte modura pairatzen zuen periferikotasuna gainditzen saiatu zen. Noski, Iparraldeko azpi-sistemak ez zion (eta hein batean oraindik ere ez dio) barkatu erasoa. Izan ere, Iparraldeko azpi-sistemaren negazioa edo auto-suntsiketarako deia baitzen Basilika. Hortik ondoko urteetan pairatu zuen bazterketa erabatekoa. Berak aitorturik dakigu Iparraldean erotzat zeukatela.

Parisen urte batzuk bizitzen eman ostean (postari gisa bertan lana aurkitu zuen), hamar bat urte geroago Itxaro Borda asmo literario berri batzuekin itzuliko da. Bere idazle ibilbidearen laugarren etapa $\mathrm{da}^{8}$, beraz, Bakean ützi arte eleberriarekin hasten dena. Etaparik interesgarriena, dudarik gabe, benetan originala bihurtzen delako Itxaro Borda, ordurarte existitzen ez zen posizioa asmatuz.

Itxaro Bordaren asmoa, pentalogia bat egitea da (bost eleberriz osaturiko obra Amaia Ezpeldoi detektibe lesbianoa -edo bisexuala?- delarik lotura egingo duena) euskal sistemaren periferiatik guneraino joanez, bai tematikoki, bai linguistikoki. Lehen atala -Bakean ützi arte- Xiberuan kokatzen da eta zubereraz idatzita dago. Bigarrena -Bizi nizano munduan- Baxe-Nafarroan kokatzen da eta osoki dago idatzia euskalki horretan. Hirugarrena -Amorezko pena baño- Nafarroako Erribera

\footnotetext{
Itxaro Borda da, behar bada, sistematikoki Hegoaldean argitaratzen hasitako lehen Iparraldeko idazlea. Noski, Mirandek ere Iparraldetik kanpo argitaratu zituen bere lanik gehienak (Iparraldeko azpi-sisteman persona non grata zelako), baina garaiak desberdinak ziren eta batez ere aldizkarietan argitaratu zituen lanak (Hegoaldean baina baita Hegoamerikan ere).

${ }^{8}$ Lehen aldia Herria-ren kolaboratzaile zenekoa litzateke, fase legitimista edo sometitua. Bigarrena Maiatz aldizkariaren sorrerari lotua litzateke, belaunaldi ordezkaketari lotutako iraultzarena. Hirugarrena, Basilikak markatzen duena : Iparraldeko literatur azpi-sistema aldatzeko edo kordokarazteko iraultzari lotua.
} 
eskualde deseuskaldunduan kokatzen da eta nagusiki baxe-nafarreraz idatzita dago. Laugarrena Bilbon edo Araban kokatuko duela iragartzen du, eta azkena "erdigunean", alegia Donostian. Autorearen asmoa, prentsan adierazi zuenez, periferiaz periferia bostgarren atalerako Donostiaraino -hots, guneraino- iristea zen. Baina, badirudi, eta nik uste zerbaiten sintoma dela, bertan behera utzi duela xedea gunerantz hurbildu ahala. Ezinezkoa balitzaio bezala gunera iristea. Proiektu erdihilaurtua izanik ere, nik uste azken urteotako xederik originaletakoena dela Itxaro Bordak planifikatutako hau. Sistema osoa (periferia+gunea) besarkatzeko ezinezko ahalegin honek zera suposatzen baitu, euskal sistemaren funtzionamendua bera aldatzeko asmoa. Periferiak gunera ekarriz (zeren ez dezagun ahantz euskal literatur sisteman nahiko zentrala den Susa argitaletxearen eskutik plazaratu direla lehen hiru atalak) eta nabarmenduz, Itxaro Bordak sistema ikusteko modu alternatiboa proposatzen du, utopikoa, berdintasun harremanean oinarritua (zergatik da gunea gune eta periferia perfieria? galdetzen du Bordak pentalogia honen bitartez). Baina, aurreko etapan ez bezala, gunera asimilatzen saiatzeko ordez bere izaera periferikoa nabarmendu egingo du (batuera baztertuz eta euskalki periferikoak aldarrikatuz, bereziki berea, nafar-lapurtera, baina baita Iparraldeko azpi-sistemaren barruan periferikoa den zuberera argitara ekarriz). Beraz, ez da ulertu behar Iparraldeko esparrura itzultzeko atzerapausu modura, baizik eta -oraingoan bere jatorrizko periferikotasuna asumiturik- periferia eta gunearen arteko harreman hierarkikoak kordokarazteko xede txit anbiziotsua bezala.

Iparraldeko azpi-sistema, halere, Bordak inarrosten edo astintzen jarraitzen du, baina beste modu batera, bere inertzia salatuz eta hizkera berri bat proposatuz. Alde horretatik, euskalkietara itzultzea ez da, Bordaren kasuan joera kontserbatzaile edo atzerakoi gisa ulertu behar, baizik eta, berriro ere, Iparraldeko azpi-sistema iraultzeko xede gisa. Beraz, bi aldiz da periferiko Borda: batetik, euskal sistemaren gune diren batuera eta Donostiaren dominazioa salatzen dituelako (euskalki dominatuetan idatziz, gainera); bestetik, Iparraldeko azpi-sistemaren gunean dagoen eta Herria aldizkari kontserbatzaileak sinbolizatzen duen nafar-lapurtera literario ortodoxoaren kontra doan hizkera literario berri bat asmatuz.

Zein den hizkera literario berri hori? Bada, nafar-lapurtera izaten jarraitzen du, baina baditu zenbait ezaugarri tradizio literario horrekiko haustura egiten dutenak: frantses maileguari beldurrik eza, egunerokotasunari lotutako mintzamoldeak eta erreferentziak erabiltzeko joera, eta orokorki harturik, garbizaletasun edo homogeneitaterik eza.

Bi galdera airean geratzen dira orain. Lehenik, nola esplikatu duela bi urteko Itxaro Bordaren Euskadi saria (saria ez al da, eskuarki, guneak guneari ematen dion zerbait, ez al da definizioz autozelebrazio bat)? Eta bigarrenik, zergatik jarraitu esaten Itxaro Borda nazionalki sarituak, Iparraldeko azpi-sisteman, periferikoa izaten jarraitzen duela?

Lehen galderak badu bere azalpen logikoa. Izan ere, jakin behar da, paradoxikoa badirudi ere, guneak beti behar duela bere ondoan (edo bazterrean, hobeto esateko) periferien presentzia. Periferiek ez diote, uste denaren aurka, guneari enbarazu egiten. Aitzitik, guneak gune izateko eta izaten segitzeko zerbaiten gune izan behar du eta hortaz, ezinbestekoa zaio bere inguruan periferia bat mantentzea ("mantendu" hitzaren zentzu guztietan: finantzatu, iraunarazi). Gainera gunea zer da? Gunea, ikuspegi historiko batetik begiratuta, beste gune potentzialak garaitu dituen periferia ohia da. Literatur sistema frantsesak literatur sistema frakonfono periferikoen beharra duen bezala, zerbaiten gune sentitzeko, bada, euskal literatur sistemak ere behar-beharrezkoak ditu Bizakiko azpi-sistema ala 
Iparraldekoa gune sentitzeko. Horregatik, guneari enbarazu egiten diona, egitekotan, ez da idazle periferikoa, baizik eta gunea inoratzen duena. Horregatik, Borda baten periferikotasun arbuiatzaile, aldarrikatzaile eta iraultzailea beharrezkoa du euskal literatur sistemak, kontestazioak berak bere zentraltasuna oroitarazten diolako guneari. Bere periferikotasun erradikalean ${ }^{9}$ Itxaro Borda guneaz gehien preokupatzen den Iparraldeko idazlea da, hots, euskal sistema etengabe gogoan duela idazten duen norbait da, eta hori da euskal sistemak saritu duena.

Bigarren galderari erantzutea falta da orain. Zergatik, Euskadi saria sakelan duelarik, esan daiteke oraindik ere Itxaro Borda Iparraldeko azpi-sisteman periferikoa dela? Nik uste arrazoia literatur sistematik at dagoela. Hizkera literario aldaketek iraultza sinbolikoa egiteko balio dute, baina iraultzak arrakasta izan dezan (hau da, hizkera berria gune bihurtu dadin indarrean zegoen zaharra ordezkatuz) aldaketa soziolinguistiko batekin kointziditu behar du. Hots, hizkera aldaketak ezin dira joan gizartea ez doan aldera. Nola edo hala konektaturik egon behar dira, nahiz posible den idazleak aldaketan aitzindari izatea (Mirande, Aresti eta Txillardegirekin gertatu zenez). Deskonexio edo desinkronizazio hori da, adibidez, Lizardi eta Lauaxetak pairatu zutena: beraien aukera linguistiko-literarioetan aitzindari izan ziren eta elite hertsi batek segituan ezagupena eman bazien ere, gerora elite hori bera damutu egin zen (gauza ezaguna da Aitzol bera izan zela saritu ondoren bi idazleok baztertu zituena). Eta okerragoa dena, etorkizun urrunagoan garaitzeko esperantza ere gerrak eraman zuen. Izan ere, gerraurreko testuinguru itxaropentsuan pentsa bazitekeen, denborarekin eta hasiberria zen alfabetizazioaren poderioz ${ }^{10}$ Lizardi batek edo Lauaxetak erabilitako euskara mota pixkanaka nagusitzen joango zela, aukera hori guztiz zapuztu zen frankismoaren etorrerak dena hankaz gora utzi zuenean. Horregatik, Lizardi eta Lauxaetaren hapax literarioak irakurtzen jarraitzen dugu, beren berezko kalitateagatik (eta suposatu zuten ahalegin sinbolikoagatik), baina iraultza literario hura hilaurtua geratu zen eta ez du gaur inork beraiek bezala idazten (ezta bururatu ere!) ${ }^{11}$. Aldiz, ñabardurak ñabardura eta salbuespenak salbuespen, denok idazten dugu Mirande, Aresti eta Txillardegik bezala, beraien oinordeko linguistikoak garelako eta geroago soziologikoki gauzatzera iritsi zen iraultza baten aitzindari izan zirelako. Hezkuntza elebidunaren hedatzeak (Trantsizio garaietik aurrera) heterodoxoen hizkera literario berria kontsumitzeko gai ziren irakurleak ugaldu zituen. Halere, zoriona ez baita inoiz erabatekoa, esan beharra dago eredu literario horren fruiturik gozoenak hurrengo belaunaldiak (Autonomiaren

9 Bidenabar, zehazta dezagun berak asmatutako hizkera literarioaren berezitasunetako bat, eta ez txikiena, honakoa dela: euskara batuaren eredutik ordurarteko Iparraldeko euskara eredua baino gehiago urruntzea. Horrek erakarri zion bere epigono dohaitsuenari (Antton Luku antzerkiegile eta ipuinegileari) Ibon Sarasola euskaltzainarengandiko haserre eta indignazioa.

${ }^{10}$ Irakasleen eskola bat abian zen Jaurlaritzaren eskutik.

${ }^{11}$ Eta behar bada berauek irakurtzen segitzen dugu poetak izan zirelako eta poesia genero marginala (periferikoa) bihurtu denez gero hizkera marginal guztien aterbe bihurtu delako. Horren froga da, a contrario, inork ez duela irakurtzen Lizardi prosaegilea. Horregatik, baita ere, Aurelia Arkotxa eta orobat Iparraldeko poetek ez dute, paradoxalki, hainbeste sufritzen Iparraldekotasunak dakarren periferizazioaz. Zeren poesia generoa berez da periferikoa euskal literatur sisteman (gero eta gehiago gainera) eta, hortaz, guneko eta periferiako prosaegileen artean dagoena baino askoz ere diferentzia txikiagoa dago Hego eta Iparraldeko poeten artean (periferiakide baitira olerkari guztiak). Hizkera berri, bitxi ala marginal guztien babesleku den poesiaren testuinguruan, Iparraldeko hizkerarik exotikoena ere da «normala », generoaren beraren marginalizazioaren irudi bihurtzen baita. 
belaunaldiak: Atxaga, Sarrionaindia etabarrek) ahoratu zituela.

Tamalez, nire uste edo beldurra da Itxaro Bordari ere beren garaiean Lizardi eta Lauxaetari gertatutakoa gertatuko zaiola. Hots, ez dela inoiz sortuko irakurle belaunaldi aski kopurutsurik berak darabilen hizkera mota ulertuko edo gozatuko duenik. Elite bat bada, noski, dagoeneko bere testuen zaporea dastatzeko gai dena, baina Iparraldeko egoera soziolinguistikoak ez du deus onik iragartzen. Populakuntzaren maila linguistikoa abiada bizian behera doa. Adin bateko belaunaldiek Daniel Landarten tankerako idazleak irakurtzen jarraitzen dute (enpatia estetiko-ideologikoan daudelako berarekin) eta belaunaldi gazteek behar bada ideologikoki hurbiltasun handiagoa sentitzen badute ere Itxaro Borda edo Antton Luku bezalako idazleekiko errazagoa dute oraindik ere, gaitasun linguistikoari dagokionez, Herria-ko hizkera literario eredua irakurtzea. Egoera horrek, nire iduriko, kalte egiten dio Iparraldeko azpi-sistema literarioari, zeren sinkronizazioa galtzen ari baita literatur bizitza eta egoera sozio-linguistikoaren artean. "Azken mohikanoaren sindromeak" jo dezake Borda eta horren froga kezkagarria litzateke (baieztatzeke geratzen den hipotesia) bere liburuak proportzioan gehiago irakurriak direla Hegoaldean Iparraldean baino. Deseperazio horren ondorio litzateke azken aldion Bordak egindako azken saioa -bere bostgarren etapa suposatuko lukeena: bere azken obra frantsesez berridatzi eta argitaratu baitu berriki euskara ez dakien Iparraldeko irakurleria gero eta zabalagoarentzat ${ }^{12}$.

\section{3-Iparraldetasuna eta Ipartasuna. Aurelia Arkotxaren Septentrio}

Gutxi dira euskal literatur sistema orokorrean toki duinean kokatzea lortu duten Iparraldeko idazleak. Eta behar bada ez da kasualitatea hori lortu dutenen artean emazteak izatea nagusi. Borda bezala, Aurelia Arkotxa ere bere periferikotasuna biderkatzen duen ezaugarri horren jabe da. Eta periferikoek dutenez sistema bat iraultzeko interesik handiena, ez gaitu harrituko Iparraldeko azpi-sistema falokratikoan menpekotasunera kondenatuak zeuden emazte bik proposatu izana delako azpi-sistema horren egoera iraultzeko bide berri ausartenak. Euskal literatur sisteman pixkanaka baina ziurki arreta lortu duen Aurelia Arkotxa ere, Borda bezala, Maiatzen ingurumarian eraturiko belaunaldi literarioaren partaide dugu. Haatik, oso bestelakoa den bide bat hartu du iparraldetasunak suposatzen duen periferikotasuna saihesteko. Probematika zail bezain originala da bere literaturgintza egituratzen

\footnotetext{
${ }^{12}$ Iragarpen ezkor horren beste froga bat litzateke, apika, ahozkotasuna Iparraldeko literatur azpi-sisteman gordetzen ari den indar ezohikoa : antzerkia eta olerkigintza kantatuaren presentzia soziala idatzizkoarena (eta bereziki eleberrigintzarena) baino askoz ere handiagoa da eta honek gutxienez bi irakurketa ditu. Batetik, sistemaren azpi-garapena salatzen du, sistemak ez duelako bermerik aurkitzen hezkuntza egituretan maila oneko irakurleria zabal eta egonkor bat eskuratzeko. Kontestu agoniko horretan, normala da ahozkotasunera jotzea, bai antzertia bai olerti errezitatu edo kantatua autoafirmazio ekintza performatiboak direlako, patu kolektiboarekin eta biziraupenarekin zerikusi zuzena dutenak. Bestalde (eta hori litzateke bigarren irakurketa) eleberrigintza, hiritartutako eta egonkortutako gizarte bati dagokio, genero dominantea izanki klase sozial dominante baten adierazmoldea delako. Iparraldeak, hain zuzen, ez dauka ezagupen ofizialik, ez da ezein botere politikoren gune, eta zaila da baldintza horietan eleberrigintza bertan garatzea (frantsesez ere ez da euskaraz baino gehiago egiten).
} 
duena, bereziki 2001ean argitaraturiko bere bigarren poema-liburuan ${ }^{13}$ (Septentrio-n) iristen dena heldutasunera. Errealismoari eta azken honek erabli ohi duen eleberriaren generoari uko eginez, poesian (edo prosa poetikoan) aurkitu du bere periferikotasuna sublimatzeko tresna. Iparraldeko euskalki literario nagusia (nafarlapurtera) euskal esparru orokorrean bigarren mailako bihurtua zela ikusirik, saiatuko da hizkera horren "elbarritasuna" abantaila bihurtzen baina -eta horretan datza Bordarekiko desberdintasuna- mintzaira bera aldatu gabe, hizkera hori urratu gabe, estetikaren bitarteko begiradaren iraultza batera bortxatuz euskal sistemako irakurlegoa. Ikusirik Iparraldea euskal literaturaren aro klasikoan -XVI. eta XVII. mendeetan- izan dela indartsuena (euskal sistemaren gune izatera iritsiz), garai hartako tematika, itsasoari eta marinel kondizioari lotua batik bat, hartzen du bere diskurtso poetikoa garatzeko. Oraindik ere kortsario eta itsasturien aroan bizi balitz bezala ari zaigu idazlea misterio kresalez zipriztinduriko Septentrio-n. Bere iruditeriak eta hizkerak Iparraldea euskarazko kulturaren gune zen garaia dakarkigu gogora etengabe. Baina ez gaitezen tronpatu, Arkotxaren mundu poetikoa (edo geopoetikoa) ukronikoa da (edo pankronikoa). la trantsiziorik gabe pasatzen gara kondairazko Persia urrun batetik (Mila eta bat gau-etakoa) gaurko ipar-amerikar paisaia izoztu batera, berriro segidan XVI. mendeko europar itsas-kroniketara itzultzeko. Ukronia genion eta utopia ere gehitu beharko genuke, edo atopia. Garai oro eta espazio oro funditzen dira hemen, batasuna, beti ere, autorearen hizkerak eta estiloak dagitelarik: hizkera homogeneoa, jasoa kultu izateraino, Sarrionandia batena oroitaraz dezakeen lexikoaren hautaketa fin baten fruitu. Territorio hau (geografiaz eta denboraz ari naiz baina baita literatur erreferentziek marrazten duten eremuaz) hain zuzen Septentrio litzateke -Iparra beraz, hots Iparraldea, gure literatur sistema aintzat hartuz gero-, periferikotasuna sinbolizatuko lukeen terrritorio literario sublimatua. Haatik Arkotxak aldarrikatzen duena ez bide da iparraldetasuna, baizik eta "ipartasuna" izendatuko duguna. Ipartasuna posizio berri bat da euskal literatur sistemaren xake-taulan, Iparraldearen egoera marginala sublimatzeko ahalegin geopoetiko ausarta. Hemen Arkotxak bilatzen eta aurkitzen duen posizioaren berritasuna Ternuari etengabe egiten zaion erreferentziak baieztatuko luke, Ternuak iparra sinbolizatzeaz gain "lur berria" esan nahi baitu, literalki. Kennet White poetak Septentrio-ren atzesolasean dioenez, "lur berrietara buruz" doa Arkotxa, "Terra incognita" batera buruz.

Modernismoek dakarten "cheap" sentsaziotik garbitu du Arkotxak bere liburuan darabilen mintzaira, eta garbizaletasun linguistikoarekin zerikusirik ez duen birginitate batera itzuli du euskara. Iparraldeko zaporea du bere hizkera literarioak, baina hizkera jaso eta estetizatua delako (inolaz ere gaurko iparraldetarren ahotan entzuten den euskara), latina, ingelesa eta orohar toponimo nahiz patronimo atzerritarrak itzulpenik gabe zitatzea gogoko duelako, Ipar Euskal Herria kurioski paisaia horretan agertzen ez delako, horregatik guztiagatik Aurelia Arkotxaren literatura ez zaigu Ipar Euskal Herriko literatura iduritzen -eta euskal literatur sistema orokorrak ere ez du horrela hartu. Denbora, espazioa, erreferentzia literarioak eta hizkera erregistroak maisuki erabiliz Arkotxak nafartar-lapurtera abstrakzio literario izatera eraman du, deskokatu du, desiparraldetu du, periferikotasun etereo bezain ideial baten hizkera bihurtzeraino ${ }^{14}$. Grekera klasikoan idatziko lukeen gaurko idazle

\footnotetext{
${ }^{13}$ Poema liburu izateari uzten dion «beste zerbait» da, egia esan, Septentrio (2001). Eta genero poetikoaren mugen zabaltze hori problematika pertsonal eta ezohiko baten eratzearen zantzu bezala irakur daiteke.

${ }^{14}$ Erran dezagun stricto sensu Aurelia Arkotxak batuera darabilela -hots, aditza batueraz datorrela bere testuetan- eta lexikoak, joskerak eta zenbait itzulik diotela ematen bere hizkera literarioari nafar-lapurtera kutsua.
} 
greziarra dirudi Arkotxak bere ukronia geopoetikoa biziarazteko nafartera-lapurtera darabilenean. Edo, bere literatur utopian egokiro txertatuko litzatekeen analogia bat egitearren, J.R.R. Tolkienen unibertso literarioan -Erdialdeko Lurralde mitikoanElfoek eta beraien hizkuntza misteriotsu bezain ederrak betetzen duen tokia beteko lukete Arkotxaren euskarak eta ipartasunak euskal sistema literarioan.

\section{4-Belaunaldi berria: eboluzio ala inboluzio?}

Bururatzeko, etorkizunaz eta belaunaldi berrietaz bi hitz esango ditugu. Badirudi azken urteetan belaunaldi berri bat agertzen hasi dela (askotan Ikastoletan ibilitako haurren lehen labealdiaren emaitzak: Eneko Bidegain, Gorka Torre, Arantxa Hirigoien). Jende gazte honek, oso nabarmenki, Iparraldeko tradiziozko hizkera literarioa hautatu du espresatzeko (Ikastolan ikasitako batueraz zipriztindua edo eguneratua, halere), berriro ildo linguistiko "legitimista" batera itzuliz. Nolanahi ere, darabilten hizkera ez da idazle hauen problematika literarioaren gune. Bestalde, ezin esan daiteke bereziki iraultzailea denik -literarioki- berauen jarduna: edukien berritze herabe bat proposatzen da (Gorka Torre baten kasuan ${ }^{15}$ ), ala tradizioaren jarraipen estetikoki kontserbatzailea (Eneko Bidegainen kasuan ${ }^{16}$ ). Edozein kasutan, ez da haustura literatura bat. Aurreko belaunaldi iraultzaileak eginiko irakurlearekiko etendura ezabatu eta berriro ere komunikazio harmoniotsu baten baldintzak jartzeko asmoa nabari da testuotan. Ez da irakurlea beldurtu edo astindu nahi, badaezpada (dirauen irakurlego urria ikaratzeko beldurrez edo). Horrela, Borda, Luku, Arkotxa eta gisa bereko idazleen belaunaldi ausart eta berritzailea lost generation bilakatzeko bidean da, no man's land batean galdurik (Hegoaldean dituztelarik irakurle gehienak eta halere modu erradikalean Iparraldetasunari loturiko problematikari eusten diotela). Eta zoritxarrez, belaunaldi etorri berriarekin galdu egin dira Maiatz-en inguruan osaturiko belaunaldiak zuen ikuspegi anbiziotsu eta orokorra (maiatz-tarrek euskal literatur sistemaren parte diren kontzientzia oso garbiaz idazten dute, beren periferikotasuna lotsarik gabe asumituz eta defendituz), maiatz-tarrek zituzten anbizio literario unibertsalistak (mundu zabaleko literaturaren ezagutzaile finak dira denak). Literatura ez da ikastolaren belaunaldiko gazteontzat gogoetagai, hizkera bere ere ez (idazle berri hauen ultra-korrekzio linguistiko zein tematikoa aipagarria da, hemen eskolan edo familian ikasitako euskara ez da auzitan jarri nahi, ez dago hizkuntzarekiko jokorik, errespetua baizik). Lekukotza literatura bat da egiten dena, kontzientzia literario urrikoa, funtzio sozial zuzen eta bat-batekoa bide du idazketak idazle gazte hauentzat, eta mezu literatura nagusitu da. Alde horretatik, eta inori irainik egin gabe (eta aintzat harturik egoera soziolinguistiko gero eta zailago batean ari direla lanean idazle gazte hauek), atzerapausu kalitatiboz mintza gaitezke, ikuspundu soilki literario batetik begiratuta. Biziraupenerako borroka testuinguru honetan inor gutxi ausartzen da, gaurko Iparraldeko idazle gazteen artean euskal literatur sistemako gunera hurbiltzen. Ez dago gunera asimilatzeko anbizio edo

\footnotetext{
${ }^{15}$ Gazte idealistak eleberrian -2001- partaide den belaunaldiaren apologia bat egiten du autoreak. Eta belaunaldi « iraultzailea » da, hain zuzen, berea : ikastolan eta burasoengandik « ikasitako » izpiritu iraultzaileak animatua. « Iraultzaren tradizioa » da hemen aldarrikatzen dena, paradoxa bada ere.

${ }^{16}$ Anbroxio izeneko bere lehen eleberrian Bidegainek ere euskal gazte engaiatu baten portreta erabat positiboa egiten du. Eta, sintomatikoki, Torreren lanean bezala, aurreko belaunaldiarekiko -kasu honetan aitatxiaren belaunaldiarekiko- errespetuan eta miresmenean oinarritzen da gazte honen euskara eta Euskal Herriarekiko « fede » politiko orbangabea.
} 
ametsik eta gunea arbuiatzeko lain ausardiarik ere ez. Iparraldeko azpisistemarentzat idazten da, xumeki edo etsipenez, ez dakigu, baina beste ametsik gabe. Egia da, baita ere, gaurko euskal sistema orain dela urte batzuetakoa baino askoz ere egituratuagoa dela eta gero eta zailagoa dela gunera hurbiltzea ${ }^{17}$.

Iparraldeko literatur azpi-sistemaren azken aldiko introbertsiorako eta inboluziorako joeraz mintzo gaitezke, beraz. Azken urteotan azpi-sistema bera ere egituratzen hasi da, behar bada bere periferikotasun iraunkorraz ohartzearen ondorioz. Bere berezitasuna nabarmendu ezik irentsia izateko arriskua sentituko bailuen. Zantzuak ugaltzen doaz, izan ere. Esaterako, garai bateko Baionako Zabal liburudendaren azken urteetan, edo oraingo Mattin Megadendan, apal berezia paratu dute Iparraldeko idazleentzat (lehen Euskal Herriko idazle guztien obrak nahasita zetozen). Ildo beretik, EKEren politika kulturala Iparraldeko kulturaren labelizazioaren aldekoa bihurtu da. Nik uste joera honi hastapena Bordak berak eman ziola orain hamar urte bere pentalogia periferikoarekin. Eta horren guztiaren gibelean kontzientzia hartze bat dagoke: "Hegoaldeko irakurleek beti nahiago izango dute originala irakurtzea kopia baino. Beraz alferrik nabil guneko literatura eta hizkera kopiatu nahiz. Has nadin nere berezitasuna lantzen."

Ikastola bihurtu da egun Iparraldeko euskaldungoaren gune erreproduzitzailea eta beraz delako euskaldungoaren "politikoki zuzenaren" ekoizle nagusia. Eta behar bada horregatik, logikoa denez, azken urteotako Iparraldeko idazle gazte berritzaileenak ikastolatik kanpoko zirkuitoetatik heldu direnak dira. Hain zuzen ikastolaren mundua bihurtu den norma linguistiko-ideologiko berriaren periferian hazi eta hezi izanak behartzen dituelako ausartago izatera toki bat egiteko. Kategoria honetan kokatuko nituzke Xabier Itzaina antzerkiegilea (Frigoa eta ni, 1999) edota Ramuntxo Etxeberri eleberriegilea (Skyroom, 2004).

Itzainaren kasuan Iparraldeko gazteria baten satira ardura garratza egiten da, hizkera legitimoa (nafar-lapurtera) erabiliz baina etengabe "modernokeriaz" lardaskatuz, errealitatean gazteria horrek egiten duen moduan. Ez da beraz, Bordaren kasuan bezala hizkera berri bat eratzeko xedea, baina bai hizkera legitimoaren urratze askatzaile edo arnas-emaile bat. Hizkera legitimoa urratzen den heinean errealitate uhainak sartzen dira obra barnera. Eta errealitate hori ez da gazte engaiatu modelikoek osatua, baizik eta orotariko fauna heteroklito batek osatua, denak (abertzale ala ez abertzale) komikotasun beraren bahetik pasatuak direlarik. Ikastolako belaunaldiak eskas duen auto-ironia -eta orohar umorea- hemen lehen planoan ezarria da. Haatik, Itzainak Iparraldeko euskaldungoaren alde tragikoa inork baino hobeki somarazten du komikotasunaren arrailduretatik pasatzen eta asmatzen utziz (joera trajikomiko edo melankoliko hau are nabarmenagoa delarik bere bigarren antzezlanean).

Ramuntxo Etxeberrik ere umorea darabil arma erretoriko nagusi bezala. Diagnostiko soziolinguistiko hotz batetik abiatuz -euskal irakurlego gaztea Iparraldean kasik ez da existitzen, ez baitu irakuzaletasunik eta kasu ainitzetan ez baitu konpetentzia linguistiko aski ere irakurle soil bihurtzeko-, modu oso pragmatikoan, kasik existitzen ez den irakurlego horri begira idazten du. Hots, euskara maila irakurlegoarenera apalduz (aitortuki gainera), balizko irakurle horri

${ }_{17}$ Zailagoa diodalarik zera esan nahi dut: gunean sartzeko eskatzen den jakintza edo konpetentzia literarioa handia dela, lehen baino handiagoa bederen. Orain dela hamarkada batzuk, inor gutxiri eskatzen zitzaion literaturan jantzia izatea -bai euskarazkoan bai unibertsalean-, euskara ondo menderatzearekin ia aski zen. Orain zuzenean periferiara zeramatza halako gabeziak. Sistema literarioa heldutasunera iristen ari den seinale, dudarik gabe. 
zuzenki mintzatuz (bigarren pertsonan idatziak dira hainbat kapitulu) baina horregatik anbizio literarioari uko egin gabe eta proselitismo euskaltzalerik egin gabe. Horrela, polar duin bezain entretenigarria idazten du, Iparraldeko gizartearen nahiz pertsonaia nagusiaren familiaren historia zati bat esploratuz. Halere, ez dago hemen ikastolako belaunaldikoen kasuan bezala, arbasoen ikuspegi hagiografikorik edo euskalduniraultzaile gizartearen apologiarik. Eta gisa berean, kanpokaldea -erdaldun gizarteaez da Etxeberriren obran ez eta Itzainarenean intrinsekoki gaiztoa.

Azken hitza, neure burua kokatzeko izango da. Ez bailitzateke zintzoa galdera hau ekiditea besteetaz mintzatzeko libertateaz baliatu ostean. Nire kasua, inori interesatzen bazaio bederen -bestela paragrafo hau aurrezteko baimena ematen zaio irakurleari, esan beharrekoak esanda baitaude dagoeneko-, atipikoa da. Iparraldeko biztanle izan naiz beti eta alde horretatik kontsidera daiteke nire joera literarioa asimilazionista izan dela (hots, euskal sistemaren gunera hurbiltzen saiatu naizela bere ezaugarrietara egokituz, batik bat hizkerari dagokionean, baina baita nire eleberrien kokapen geografiko aldakorrari begiratuz). Eta hala da, baina ez erabat. Izan ere, ama bizkaitarra eta aita gipuzkoarra ditudanez gero, eta burasoen hautuz, guneko batuera etxekoa dudanez gero ${ }^{18}$, ez bainaiz guztiz asmilatua. Neurri batean guneko idazle jator gisa ere ikusten dut neure burua. Bestalde, nire lanetan, ausaz bitarteko egoera batean aurkitzen naizelako eta erdi-periferiko erdi-guneko sentzitzen naizelako, garrantzi handia eman izan diot beti espazioari eta hizkera ezberdinen arteko jokoari. Sistema bere osotasunean (bere periferia barne) erretratatzen saiatu naizela, alegia, ahal bezain errealista izateko asmoz. Kosmopolitismo intra-euskaldun bat sortu nahi izan dut hasieratik. Hots, Euskal Herri osoa nire eremu naturala bailitzan sentitzen dut (edo sentitu nahi nuke, hori baita nire utopia pertsonala), edo modu negatiboago batean esanez, euskaraz idazten dudanean euskalduna naiz, bai, baina ez toki jakin batekoa. Nonbaitekoa izatekotan, Mirandek nahiz Paillenek behiala ziotenez Paristar euskalduna bainaiz (han sortua izaki)! Boutade-ak baztertuta, ezer baino lehen eleberriegile errealistatzat daukat neure burua.

${ }^{18}$ Etxean batueraz mintzatu gara beti eta ez gipuzkeraz ala bizkaieraz, burasoen ideal politikoarekiko koherentziaz nik uste. 